but falls. The inability of insects to crawl up against the points of the hairs I have often tested in the most satisfactory manner" (Trans. Linncan. Society, vol, xii.). I have again and again released blue-bottle lies after they have been trapfed, and have never yet found them act in any way that would suggest an intoxicating property in the secretion which they had fed upon - this is contrary to the information of "W. C. MI.," who says:- "After fceding noon the secretion for two or three minutes they [the insects] become quite stupil, unsteady on their fect, \&c." To prevent the pitchers being injurcd by the large number of insects which are lures into them, we find it necessary at Kew to fill the mouths of the pitchers with cottonwool; this prevents the insects from falling in. Before this precaution was taken many of our finest pitchers were lost, owing to the decay which was caused by the rotten mass of insects which had accumulated in the bottom of the pitchers, "W. C. M." will be surprised to hear that, in spite of this cutting off of the supply of insects to the pitchers, the plant were in no way affected as regarded growth or vigour, but that the length and general health of the pitchers were more satisfactory after the insects were not allowed to enter them, than before. The concluding sentence in his remarks is rather start ling, as, so far as investigations conducted by physiologists have gone hitherto, the Sarracenias are not known to be carnivorous. Mr. W. II. Gilburt, of the Quekett Microscopical Club, says :"The pitchers contain fluid, but nothing corresponding to a digestive fluid has been detected in them ; so that, if the insects which perish in the pitcher are of any value to the plant and afford any nutriment, it inust be simply by maccration, and the glands can be regarded as absorbent only." Of course it may be said that Sarracenias woukl not have been constructed with what appears to be a view specially to catching insects, if the insects were not to scrve some useful purpose in the economy of the plant. Anyhow, at present it is only safe to say of Sarracenias that they allure and ultimately destroy insects, but we do not yet know that they uldain nuurishment from them. Certainly under cultivation there is abundance of cvidence to prove that these, and in fact all those plants which are considered to be distinclly carnivorous, grow and thrive at last as well when insect food is not allowed them as when it is.

Kew

W. WATSON

\section{Colourless Chlorophy11}

IN his elaborate "Contributions to the Chemistry of Chlorophyll" (NATURE, vol. xxxii. p. II7), Mr. E. Schunck rightly obscrves that the explanation given by $\mathrm{Mr}$. T'schirch for the curious fact discovered by Mr. Church is not based on sufficient proof. Indeed it could harlly be admitted that the action of metallic zinc is a process of reduction, since a similar result may be arrived at when zinc oxide is used instead of the metal. (A fact that I stated in 1869 ).

But quite recently I have had the opportunity to convince myself that the reaction that takes place when a chlorophyll solution is treated by metallic zinc and an organic acid is of an utterly differcnt nature. Through the agency of nascent hydrogen generated in the reaction, chlorophyll is actually reducte, the resulting substance bing not of a green colour, but perfectly colourless, and presenting no traces of the characteristic chlorophyll spectrum or fluorescence. It is only on coming in contact with the air that it gradually acquires both its green colour and specific optical properties. It is highly instructive to watch the phenomenon in a test-tube placed before the slit of a spectroscope and observe the first appearance and subscquent growth of the dark bands, the colourless substance regaining in the mean while its original splendid emerald green.

The physiological importance of this fact will be obvious to all botanists interested in the subject ; for my part I consider that the discovery of this colourless modification of chlorophyll brings additional proof in favour of an hypothesis that I proposed in 1875 concerning the chemical nature of chlorophyllviz. that the green colour of this substance is due to the presence of iron in the state of a $\mathrm{FeOF}_{2} \mathrm{O}_{3}$ compound. In fact, all the changes that this substance undergoes, its production, its destruction, the action of acids, of metallic zinc and zinc oxide, might be easily accounted for by admitting this simple and very plausible hypothesis.

But whatever may be the ultimate fate of this "provisional" hypothesis, the fact just stated will lose nothing of its importance. Its chief interest lies in the establishment of the existence of a colourless substance, acquiring by oxidation all the optical properties of chlorophyll. It is evident that chlorophyll is gencrated in this case by a process similar to that which takes place in the living plant. (The existence of such a substance has been often announced, but continues to be a subject of doubt). At the same time we may sce the reason why, admitting that chlorophyll undergoes a process of reduction when $\mathrm{CO}_{2}$ is dissociated through the agency of light (this supposition is highly probable), this transformation may not be attended by a visible change of its colour, and other optical properties-the produce of reduction being colourless and having no dark lines in the spectrum. However, the change of colour that M. Sachs observed in a great number of leaves on exposing them to direct sunlight, and which is generally attributed to a migration of the chlorophyll grains, might, partly at least, be due to this process of reduction.

Moscow, July I 5

C. TIMIRIAZEFF

\section{July Meteors}

BE'TWEEN July 8 and I4, I I shooting stars were recorded here in $I I \frac{3}{4}$ hours of observation. The paths of these, reproduced upon an I8-inch celestial globe, enabled me to fix the radiant points of 12 showers with considerable distinctness :-

$$
\begin{aligned}
& \begin{array}{cccccc}
\text { No. } & \text { Epoch. } & \text { July. } & \text { Radiant. } & 0 \\
\text { I } & \ldots & \text { I3 } & \text { I4 } & \ldots & \text { II }+48
\end{array} \quad \text { Meteors long, swift with streaks. } \\
& \begin{array}{rrrrrrr}
\text { I } & \ldots & \mathbf{I}_{3}-\mathbf{I} 4 & \ldots & \text { I I }+48 & \text { Meteors long, swift with st } \\
2 & \ldots & 8 & 8-13 & \ldots & 245+52 & \text { Slow, yellow, max. July } 8 .
\end{array}
\end{aligned}
$$

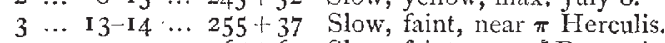

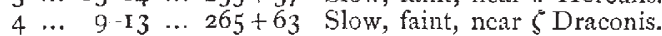

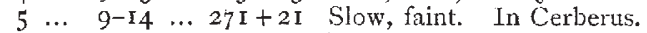

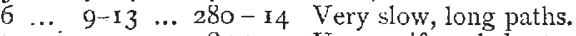

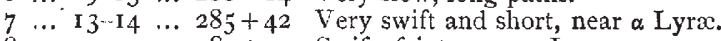

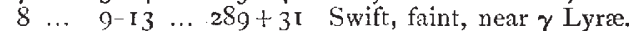

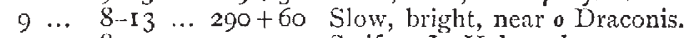

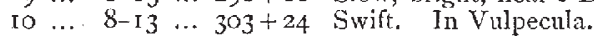

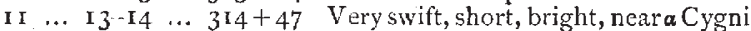
$\begin{array}{lllllll}12 & \ldots & 9-14 & \ldots & 329+36 & \text { Swift, reddish streaks. S. of Lacerta. }\end{array}$ Nos. I, 7, 8, 9, II, and I 2 were well observecl by Zezioli in I 867-68, and form Nos. $93,90,88,89,99$, and 98 of the catalogue of radiants derived by Schiaparelli from his observations.

Generally the metcors observed here during the past month were small, but three were estimated as bright as Jupiter. The first of these appeared on July 8 at I.2h. Im., slooting rapidly along a course of 27 degrees a little west of $\zeta, \eta, \theta$ Draconis. It left a brilliant streak, enabling the path to be very accurately noted. This metcor bclonged to the radiant at $\mathbf{I I}^{\circ}+48^{\circ}$, and soon afterwards, at $12 \mathrm{~h}$. rom, another fine one was seen pur. suing a sreatly foreshortened path near $\delta$ Draconis and throwing off a dense train of yellowish sparks. Its motion and appearance prove it to have been a Draconid and a member of the display from $290^{\circ}+60^{\circ}$. On July 9 , at $\mathbf{I} 3 \mathrm{~h}$. $50 \mathrm{~m}$., I recorled a fine meteor shooting upwards, just east of Altair, from a centre at $304^{\circ}-15^{\circ}$ near $\alpha$ and $\beta$ Capricorni ; but I have not included this position in the list, as $I$ only saw one other shooting star with a conformable dircetion during the period included by my observations.

On July 3I a few fine and early members of the August Perseids were seen, and on August I, between $9 \mathrm{~h} .45 \mathrm{~m}$. and $9 h$. 50m., I noted three others, two of which were unusually brilliant, and projected vivicl streaks upon their long, graceful fights through the Milky Way west of Aquila. This conspicuous and early appearance of the Perseids would seem to predicate a bright maximum on the night of August ro.

Bristol, August 2

$$
\text { W. F. DEnNing }
$$

\section{The August Meteors}

LAST night at 9.32 a brilliant meteor crossed Cassiopeia's Chair from W. to E. parallel to the horizon. Its trail was visible for twenty-six scconds after the bursting of the meteor. During a five mile walk, lighted by many meteors, the summer lightning incessantly flashed from the northern horizon, but its brightness was never comparable to that of this meteor. It resembled most a magnesium rocket in the Crystal Palace fireworks. But even this comparison is hardly adequate.

Chatham, August I2

$$
\text { H. B. JUPP }
$$

\section{A Possible Windfall for Science}

Is not the better course for immediate action that the departments in England and the United States should first combine? 